\title{
APLIKASI TEKNOLOGI PENGINDERAAN JARAK JAUH UNTUK MENGIDENTIFIKASI \\ HEAT ISLAND ("PULAU PANAS") DI KOTA PEKANBARU
}

\author{
Muhammad Ikhwan', Hadinoto' \\ ${ }^{1}$ Staf pengajar Fakultas Kehutanan Universitas Lancang Kuning \\ Jln. Yos Sudarso Km. 8 Rumbai Pekanbaru Riau \\ Telp./Fax. (0761) 54092 \\ Email : mmighwan@yahoo.com, hdinto@yahoo.co.id
}

\begin{abstract}
The increasingly development in Pekanbaru city caused the environmental change. This condition also affected to the increased of surface temperature on the urban area of Pekanbaru City. The increasing of surface temperature will lead the increasing of air temperature which could impact to the uncomfortable activity in Pekanbaru City. The high air temperature in urban areas is caused by increasing built-up areas and declining green open space. Green open space should be built to lower air temperature and to create a comfortable micro climate. Green open space should be developed at locations with high air temperature to reach its efficiency. The research was aimed to identify the phenomena of Heat Island in Kota Pekanbaru. The processing satellite image data of band 6 of Landat 7 ETM+ was conducted to produce the distribution of surface temperature in Pekanbaru City. The results shows that, the surface temperature of the urban area is higher than the green open space area, especially for residence area, road, office building area and bare land. This condition indicates that the phenomena of Heat Island accurs in Pekanbaru City.
\end{abstract}

Keywords : built up area, green open space, surface temperature, remote sensing 


\section{PENDAHULUAN}

Perkembangan

Kota

Pekanbaru akibat pembangunan infrastruktur yang berupa pembangunan fisik seharusnya tetap memperhatikan keseimbangan ekosistem dan kualitas lingkungan yang baik. Tapi kenyataannya hal tersebut tidak pernah dijumpai dalam kegiatan pembangunan infrastruktur Kota. Sejak tahun 2000 hingga sekarang, wilayah Kota Pekanbaru telah mengalami perubahan penutup lahan yang cukup berarti. Hal ini ditandai dengan meningkatnya pembangunan pemukiman, ruko, gedung perkantoran dan jalan dan semakin berkurangnya kawasan ruang terbuka hijau

Pesatnya perkembangan dan pemekaran wilayah di Kota Pekanbaru telah merubah lansekap kota. Banyak ruang terbuka hijau yang telah dijadikan sarana dan prasarana publik, yang berdampak pada perubahan penutupan dan penggunaan lahan. Perubahan penutupan lahan dapat merubah reflektansi radiasi surya permukaan bumi dan menyebabkan pendinginan ataupun pemanasan lokal (Handayani, 2007). Perubahan lingkungan yang terjadi tersebut berdampak pada perubahan pada unsur-unsur iklim. Perubahan unsur iklim yang terjadi adalah pada suhu, radiasi matahari, kecepatan angin, dan keawanan.

Dari empat unsur iklim tersebut, yang dapat dirasakan langsung perubahannya adalah suhu. Perubahan tataguna lahan ataupun konversi lahan karena aktivitas manusia yang terjadi di kota Pekanbaru mempengaruhi kondisi suhu permukaan, yang selanjutnya mempengaruhi suhu udara. Bahan bangunan seperti aspal, semen, dan beton menjadi penyerap dan penyimpan panas matahari (Tursilowati, 2002). Suhu pada wilayah perkontoran 
dan jalan aspal mengalami perubahan yang tinggi, berbeda dengan kawasan yang bervegetasi yang memiliki suhu permukaan yang lebih rendah. Adanya perbedaan suhu dikawasan kota yang padat bangunan dengan kawasan dipinggiran kota yang masih didominasi oleh tutupan vegetasi dikenal dengan istilah heat island atau "pulau panas".

Pengkonversian

lahan bervegetasi menjadi kawasankawasan pembangunan di daerah perkotaan menyebabkan beberapa dampak negatif pada lingkungan. Meningkatnya suhu udara dapat mengurangi mutu lingkungan hidup, berkurangnya kenyamanan kota dan buruknya kualitas udara di kawasan perkotaan yang berdampak pada menurunnya tingkat kesehatan masyarakat. Selain itu, polutanpolutan yang berbentuk gas dan partikel kecil di atmosfer seperti $\mathrm{CO}, \mathrm{CO}_{2}, \mathrm{~Pb}, \mathrm{NOx}, \mathrm{SO}$, dan CFC yang merupakan hasil aktivitas kegiatan manusia, akan bergerak dan terkonsentrasi menuju kawasan-kawasan yang bersuhu lebih tinggi.

Dengan

demikian

diperlukan adanya pembangunan wilayah yang terencana untuk menjaga dan memperbaiki kualitas udara di Kota Pekanbaru. Pembenahan tata ruang perkotaan dengan menentukan kawasan-kawasan untuk tiap penggunaan lahan. Oleh karena itu perlu dilakukan suatu kajian tentang sebaran suhu permukaan pada berbagai penutupan lahan di Kota Pekanbaru. Harapan jangka menengah dan panjangnya adalah Kota Pekanbaru menjadi kota yang lebih nyaman, lebih bersih dan lebih sehat.

Teknologi yang dapat digunakan untuk mendapatkan informasi dengan cepat tentang jenis penutupan lahan dan sebaran suhu permukaan di Kota 
Pekanbaru adalah dengan menggunakan data penginderaan jauh atau citra satelit sumberdaya, khusunya citra Landsat. Citra satelit Landsat mampu memberikan data yang diperoleh dengan cepat, tepat dan berkesinambungan yang mampu merekam kondisi penutupan lahan setiap periode waktu tertentu sehingga perubahanperubahan yang terjadi di Kota Pekanbaru pada rentang waktu tertentu dapat dideteksi dan diidentifikasi setiap saat.

Tujuan dari penelitian ini adalah mengidentifikasi fenomena Heat Islands di Kota Pekanbaru.

\section{METODE PENELITIAN}

\section{Lokasi dan Waktu Penelitian}

Penelitian ini dilakuan di Kota Pekanbaru yang secara geografis terletak antara $101^{\circ} 18^{\prime}$ Bujur Timur sampai $101^{0}$ 36' Bujur Timur serta $0^{0} 25^{\prime}$ Lintang Utara Sampai $0^{0} 45^{\prime}$ Lintang Utara. Kota
Pekanbaru memiliki luas wilayah sebesar $632,26 \mathrm{~km}^{2}$, yang secara administratif berbatasan dengan sebesal Utara dan Timur dengan Kabupaten Siak, sebelah Selatan dengan Kabupaten Pelalawan dan sebelah Barat berbatasan dengan Kabupaten Kampar.

Kegiatan Penelitian ini dilaksanakan dari Bulan Maret 2015 sampai Mei 2015.

\section{Bahan dan Alat Penelitian}

Bahan yang digunakan pada penelitian ini adalah :

a. citra band 6 Landsat 7 ETM+ path/row 127/60 untuk liputan wilayah Kota Pekanbaru untuk akuisisi tanggal 13 Mei 2012 yang digunakan sebagai bahan untuk diekstrak menjadi data suhu permukaan.

b. Peta digital batas administrasi Kota Pekanbaru

Alat yang digunakan pada penelitian ini adalah :

a. seperangkat komputer beserta asesorisnya 
b. perangkat lunak atau software ERDAS Imagine versi 8.5 untuk pengolahan data citrn Landsat 7 ETM+

c. perangkat lunak atau software Arc View GIS versi 3.2 untuk proses digitasi dan pemetaan.

d. Kamera digital

Alat GPS (global positioning system) untuk memperoleh data koordinat penutupan lahan di Kota Pekanbaru.

\section{Metode dan Analisis Penelitian}

Kegiatan penelitian ini diawali dengan mempersiapkan perangkat-perangkat keras (komputer) dan perangkat lunak (software Erdas Imagine dan ArcView GIS). Selanjutnya adalah mengumpulkan data-data yang diperlukan. Adapun data yang dikumpulkan dapat dibagi dua jenis yaitu data primer dan data sekunder. Data primer pada penelitian ini adalah data-data hasil pengecekan dilapangan seperti : data suhu udara pada setiap tutupan lahan yang ada di Kota Pekanbaru beserta dokumentasinya dan data koordinat jenis tutupan lahan tersebut. Pada penelitian ini, kegiatan pengumpulan data diawali dengan pengumpulan data sekunder. Data sekunder tersebut adalah data citra satelit band 6 Landsat 7 ETM+ yang diperoleh (dibeli) dari PT. Waindo SpecTeraa dan data peta digital untuk wilayah administrasi Kota Pekanbaru yang diperoleh dari Dinas Kehutanan Propinsi Riau.

Tahap pertama dalam pengolahan data adalah melakukan pengolahan data citra band 6 yaitu proses mengkonversi nilai kecerahan (brightness temperature) menjadi nilai suhu permukaan dalam satuan derjat celcius. Selanjutnya untuk menelaah kembali hasil interpretasi obyek/jenis tutupan lahan pada citra, maka dilakukan pengecekan ke lapangan (ground check) dan pengambilan data 
koordinat dengan menggunakan alat GPS eTrex. Pengambilan data koordinat ini dilakukan pada setiap jenis tutupan lahan yang ada di Kota Pekanbaru yang disesuaikan dengan citra hasil pengklasifikasian.

Setelah pengecekan lapangan selesai, selanjutnya dilakukan pengolahan data citra satelit Landsat 7 ETM khususnya pada band/kanal 6 untuk menghasilkan data suhu permukaan pada berbagai tutupan lahan yang ada di Kota Pekanbaru dan sekitarnya. Citra hasil olahan dari band 6 yang menggambarkan suhu permukaan Kota Pekanbaru dan sekitarnya dianalisis secara deskriptif untuk mendapatkan informasi tentang ada atau tidaknya fenomena Heat Island di Kota Pekanbaru.

\section{HASIL DAN PEMBAHASAN}

Penutupan Lahan di Kota Pekanbaru
Penutupan lahan berkaitan dengan jenis kenampakan yang ada di permukaan bumi, contoh jenis penutup lahan adalah bangunan perkotaan, danau, vegetasi dan lain-lain. Sedangkan istilah penggunaan lahan berkaitan dengan kegiatan manusia pada bidang lahan tertentu (Lillesand dan Kiefer (1997). Menurut Lo (1995) bahwa penutupan lahan menggambarkan kontruksi vegetasi dan buatan yang menutup permukaan lahan. Kontruksi tersebut seluruhnya tampak secara langsung dari citra penginderaan jauh.

Kota

Pekanbaru

mempunyai luas wilayah 632,26 $\mathrm{km}^{2}$ atau 63.226 Ha. Menurut Ikhwan (2013) bahwa Hasil penelitian Ikhwan (2013) menunjukkan, bahwa berdasarkan hasil klasifikasi citra satelit Landsat 5 TM tahun 1989 dan citra Landsat 7 ETM+ tahun 2012, Kota Pekanbaru mengalami 
perubahan penutupan lahan pada setiap tipe penutupan lahannya. Dalam kurun waktu dari tahun 1989 - 2012 (23 tahun) telah terjadi peningkatan dan penurunan luas wilayah penutupan lahan yang terdapat di Kota Pekanbaru. Perubahan lahan yang terjadi tersebut disajikan pada Tabel 1.

Tabel 1. Perubahan Penutupan lahan Kota Pekanbaru tahun 1989-2012

\begin{tabular}{|c|c|c|c|c|c|}
\hline \multirow{2}{*}{ No. } & \multirow{2}{*}{ Penutupan Lahan } & \multicolumn{2}{|c|}{ Tahun 1989} & \multicolumn{2}{|c|}{ Tahun 2012} \\
\hline & & $\mathrm{Ha}$ & $\%$ & $\mathrm{Ha}$ & $\%$ \\
\hline 1. & Hutan (sekunder) & $15.337,1$ & 21,6 & $2.359,89$ & 3,91 \\
\hline 2. & Lahan/tanah kosong & $5.910,6$ & 8,33 & $17.811,3$ & 29,5 \\
\hline 3. & Badan air & 994,23 & 1,40 & 869,76 & 1,44 \\
\hline 4. & Kawasan terbangun & $8.499,9$ & 11,9 & $11.202,4$ & 18,5 \\
\hline 5. & Rumput & $7.697,4$ & 10,8 & - & - \\
\hline 6. & Semak/Belukar & 28.764 , & 40,5 & $23.595,1$ & 39,1 \\
\hline 7. & $\begin{array}{l}\text { Tidak ada data (awan } \\
\text { dan bayangan awan) }\end{array}$ & $3.770,0$ & 5,31 & $4.549,68$ & 7,53 \\
\hline & Jumlah & $70.975,0$ & 100,0 & $60.388,20$ & 100 \\
\hline
\end{tabular}

Sumber : Ikhwan (2013)

Pada Tabel 1 Sedangkan yang mengalami memperlihatkan bahwa penurunan adalah penutupan perubahan penutupan lahan yang lahan semak bhelukar dan hutan. terjadi dalam periode 1989-2012 Penutupan lahan tanah kosong di Kota Pekanbaru ada yang dari luas kawasan 5.910,57 ha mengalami penambahan dan pada tahun 1989 menjadi pengurangan. Kawasan yang 17.811,27 ha pada tahun 2012 . mengalami penambahan adalah Peningkatan luas tanah kosong ini penutupan lahan tanah/tanah berasal dari konversi tutupan kosong, dan area terbangun. lahan semak belukar dan padang 
rumput yang akan dijadikan kawasan terbangun seperti pemukiman dan bangunanbangunan perkantoran dan unitunit usaha (ruko). Selain dijadikan sebagai kawasan terbangun, lahan-lahan tanah kosong ini akan digunakan untuk kegiatan pertanian dan perkebunan sawit. Penutupan lahan kawasan terbangun pada tahun 1989 adalah $8.499,87$ ha dan meningkat menjadi $11.202,48$ ha pada tahun 2012. Penigkatan luas kawasan terbangun ini tidak terlepas dari meningkatnya jumlah penduduk Kota Pekanbaru dari tahun ke tahun yang tentunya penduduk ini memerlukan tempat tinggal dan tempat usaha. Penutupan lahan hutan mengalami pengurangan, dari luas $15.337,17$ ha pada tahun 1989, hanya tinggal menjadi 2.359,89 ha. Sebagian besar kawasan hutan ini telah berubah menjadi tanah kosong, semak belukar, area terbangun, pertanian dan perkebunan. Hutan yang masih tetap ada dan terjaga keberadaannya adalah hutan yang ada di kawasan PT. Chevron, hutan yang ada di kawasan Universitas Lancang Kuning dan hutan konservasi Tahura Sultan Syarif Hasim. Tidak hanya penutupan lahan hutan saja yang mengalami penurunan, penutupan lahan semak belukar berkurang luasnya dari 28.764,99 ha pada tahun 1989 menjadi 23.595,12 ha pada tahun 2012. Tapi meskipun semak belukar ini mengalami pengurangan, penutupan lahan semak belukar ini masih mendominasi penutupan lahan yang ada di Kota Pekanbaru Sebaran Suhu Permukaan Kota
Pekanbaru dan Sekitarnya

Hasil pengukuran data suhu dan titik koordinat lokasi pada berbagai penutupan lahan di Kota Pekanbaru dapat dilihat pada Tabel 2. 
Tabel 2. Data suhu dan titik koordinat penutupan lahan

\begin{tabular}{|c|c|c|c|c|}
\hline \multirow[t]{2}{*}{ No. } & \multirow{2}{*}{$\begin{array}{c}\text { Jenis } \\
\text { Penutupan Lahan }\end{array}$} & \multirow{2}{*}{$\begin{array}{c}\text { Suhu } \\
\left({ }^{0}\right)\end{array}$} & \multicolumn{2}{|c|}{ Titik Koordinat } \\
\hline & & & Bujur Timur & Lintang Utara \\
\hline 1. & $\begin{array}{l}\text { Pemukiman } \\
\text { masyarakat }\end{array}$ & 35 & $101^{0} 26^{\prime} 09,10^{\prime \prime}$ & $0^{0} 34^{\prime} 01,95^{\prime \prime}$ \\
\hline 2. & Jalan Aspal & 32,8 & $101^{0} 25^{\prime} 44,42^{\prime \prime}$ & $0^{0} 34^{\prime} 30,64^{\prime \prime}$ \\
\hline 3. & Hutan alam sekunder & 28 & $101^{0} 25^{\prime} 33,65^{\prime \prime}$ & $0^{0} 34^{\prime} 28,68$ " \\
\hline 4. & Kebun Sawit & 31,5 & $101^{0} 25^{\prime} 35,31^{\prime \prime}$ & $0^{0} 34^{\prime} 35,71^{\prime \prime}$ \\
\hline 5. & HTI Ekaliptus & 31,3 & $101^{0} 25^{\prime} 26,40^{\prime \prime}$ & $0^{0} 34^{\prime} 44,07$ “ \\
\hline
\end{tabular}

Berdasarkan

pengolahan pada band/kanal 6 citra Landsat 7 ETM+ tahun 2012 untuk wilayah Kota Pekanbaru dan sekitarnya, diperoleh sebaran suhu permukaan berkisar antara $12,94{ }^{\circ} \mathrm{C}$ sampai $30,38{ }^{\circ} \mathrm{C}$ seperti yang disajikan pada Gambar 1.

Gambar 1 Memperlihatkan citra hasil pengolahan band 6 pada Landsat 7 ETM+ untuk wilayah Kota Pekanbaru dan sekitarnya. Citra ini menjelaskan sebaran suhu permukaan dalam satuan derjat celcius yang secara visual terlihat sebagai warna hitam, abu-abu dan putih. Wilayah atau kawasan yang berwarna hitam merupakan kawasan yang memiliki suhu permukaan yang rendah.

Kawasan yang berwarna abu-abu dan putih merupakan kawasan yang memiliki suhu permukaan yang lebih tinggi dibandingkan yang berwarna hitam

Untuk memudahkan dalam menginterpretasi sebaran suhu permukaan secara visual pada citra ini, maka dilakukan pengolahan dengan mengelompokkan nilai-nilia suhu pada citra tersebut dengan menggunakan metode unsupervised classification. Pada metode ini, sebaran suhu permukaan di wilayah Kota Pekanbaru dan sekitarnya di kelompokkan menjadi 6 (enam) kelas. untuk dapat melihat 
perbedaan sebaran suhu permukaan, maka citra dengan enam kelas ini diberi warna. Hasil pengolahan dapat dilihat pada Gambar 2.

Gambar 2 memperlihatkan sebaran suhu permukaan di Kota Pekanbaru dan sekitarnya (sebagian Kabupten Kampar dan Kabupaten Pelalawan) terdiri dari 6 kelas yang diwakili oleh 6 warna yang berbeda. Suhu permukaan $12,94{ }^{\circ} \mathrm{C}$ sampai $17,82{ }^{\circ} \mathrm{C}$ diberi warna biru, suhu permukaan $20,93{ }^{\circ} \mathrm{C}$ sampai $22,80{ }^{\circ} \mathrm{C}$ diberi warna biru muda, suhu permukaan $22,89{ }^{\circ} \mathrm{C}$ sampai $23,70{ }^{\circ} \mathrm{C}$ diberi warna hijau muda, suhu permukaan $24,73^{\circ} \mathrm{C}$ sampai $25,19{ }^{\circ} \mathrm{C}$ diberi warna kuning, suhu permukaan $26,05{ }^{\circ} \mathrm{C}$ sampai 26,74 ${ }^{\circ} \mathrm{C}$ diberi warna merah muda dan suhu permukaan 27,08 ${ }^{\circ} \mathrm{C}$ sampai $30,38{ }^{\circ} \mathrm{C}$ diberi warna merah.

Secara visual dari Gambar 5.2 juga memperlihatkan bahwa sebaran suhu permukaan di Kota pekanbaru adalah antara $12,94^{\circ} \mathrm{C}$ (suhu permukaan terendah) sampai $30,38^{0}$ C (suhu permukaan tertinggi). Suhu permukaan berkisar antara $24,73^{\circ}$ $\mathrm{C}-30,38^{\circ} \mathrm{C}$ secara visual pada Gambar 5.2 adalah berwarna kuning, merah muda dan merah, terlihat di pusat kota pemerintahan dan pemukiman padat penduduk di Kecamatan Tampan, Kecamatan Bukit Raya dan Kecamatan Marpoyan Damai. Sementara itu, di luar kawasan Kota Pekanbaru, yaitu sebagian wilayah Kabupaten Kampar, suhu berkisar antara $12,94^{\circ} \mathrm{C}$ sampai $22,8^{\circ} \mathrm{C}$ yang pada Gambar 4.2 secara visual terlihat berwarna biru muda dan hijau muda. Adanya data yang memperlihatkan bahwa suhu di pusat kota lebih tinggi dibandingkan suhu disekitarnya (sebagaian wilayah Kabupaten Kampar) yang lebih rendah, maka berdasarkan data tersebut, fenomen Heat Island (pulau 
panas) di Kota Pekanbaru sudah mulai ada. Tapi fenomena yang juga telihat secara visual dan data hasil penelitian memperlihatkan bahwa suhu permukaan tertinggi terdapat pada kawasan pemukiman padat penduduk di Kecamatan Tampan dan Kecamatan Bukit Rata yang mencapai $30,38^{\circ}$ C. Hal ini disebabkan oleh semakin tingginya pembangunan pemukiman oleh para pengembang (developer) dan pendirian bangunan ruko, jalan aspal dan pusat-pusat perbelanjaan di Kecamatan Tampan dan Bukit Raya.

Miller (1986) mengatakan bahwa bangunan beton dan aspal menyerap panas sepanjang hari dan melepaskannya secara lambat pada malam harinya. Sedangkan pada vegetasi (Curran 1985 dalam Sutanto 1987) menyatakan bahwa suhu harian vegetasi variansinya lebih kecil daripada bangunan beton, karena pada siang hari vegetasi menyerap sinar matahari dalam jumlah besar, akan tetapi karena adanya transpirasi yang cukup tinggi maka pada siang hari terjadi pendinginan, tingginya transpirasi dapat mengurangi suhunya pada siang hari. Keberadaan vegetasi dalam jumlah banyak tidaklah mungkin pada daerah urban, melainkan pada daerah rural. Sementara daerah urban tentunya memiliki suhu lebih tinggi akibat kepadatan bangunan berstruktur material beton dan jalan beraspal sebagai wujud kontribusi kota ntuk menyediakan kelayakan infrastruktur. Perbedaan suhu antara daerah urban dan rural yang cukup tajam ini membentuk suatu perbedaan "bahang" (panas), fenomena ini dikenal sebagai pulau bahang perkotaan atau Urban Heat Island (UHI) dicirikan seperti pulau udara permukaan panas yang terpusat di area urban dan akan akan semakin turun temperaturnya di 
daerah sekelilingnya pada daerah suburban / rural (Tursilowati, 2007)

Hasil penelitian Ikhwan (2013) menunjukkan sebaran suhu permukaan di Kota Pekanbaru pada tahun 1989 berkisar antara 9,4 ${ }^{\circ} \mathrm{C}$ hingga
$19,74{ }^{\circ} \mathrm{C}$. Suhu permukaan ini merupakan suhu permukaan pada berbagai penutupan lahan (land cover) di Kota Pekanbaru. Nilai suhu permukaan pada berbagai penutupan lahan di Kota Pekanbaru dapat dilihat pada Tabel 3.

Tabel 3. Suhu Permukaan Pada Berbagai Penutupan Lahan Di Kota Pekanbaru Tahun 1989

\begin{tabular}{ccl}
\hline No. & $\begin{array}{c}\text { Suhu } \\
\text { Permukaan } \\
\left({ }^{\circ} \mathrm{C}\right)\end{array}$ & Penutupan Lahan \\
\hline 1. & $9,40-13,95$ & Badan air (sungai, danau, kolam) \\
\hline 2. & $10,94-17,36$ & Hutan \\
\hline 3. & $11,95-18,32$ & Semak belukar \\
\hline 4. & $13,45-16,39$ & Padang rumput \\
\hline 5. & $13,45-19,27$ & Lahan atau tanah kosong \\
\hline 6. & $13,95-19,74$ & $\begin{array}{l}\text { Area terbangun (pemukiman, jalan, gedung } \\
\text { perkantoran swasta dan pemerintahan) }\end{array}$ \\
\hline & Sumber : Hasil Penelitian (Ikhwan, 2013)
\end{tabular}

Pada

Tabel

memperlihatkan bahwa sebaran suhu permukaan terendah terdapat pada penutupan lahan badan air (sungai, anak sungai, danau, kolam) dengan rentang antara $13,95{ }^{\circ} \mathrm{C} \quad-9,40{ }^{\circ} \mathrm{C}$. Selanjutnya penutupan lahan hutan memiliki sebaran suhu permukaan antara $10,94{ }^{\circ} \mathrm{C}$ $17,36{ }^{\circ} \mathrm{C}$. Sebaran suhu permukaan pada penutupan lahan
3 semak belukar antara $11,95^{\circ} \mathrm{C}$ 18,32 ${ }^{\circ} \mathrm{C}$, sebaran suhu permukaan pada padang rumput sebesar $13,45^{\circ} \mathrm{C}-16,39{ }^{\circ} \mathrm{C}$. Penutupan lahan dengan sebaran suhu permukaan antara $13,45^{\circ} \mathrm{C}$ hingga $19,27^{\circ} \mathrm{C}$ adalah tanah kosong dan area terbangun memiliki sebaran suhu permukaan antara $13,95^{\circ} \mathrm{C}-19,74^{\circ} \mathrm{C}$.

Selama periode antara tahun 1989 sampai 2012, telah 
terjadi peningkatan suhu terbangun di Kota Pekanbaru . permukaan antara kawasan $\mathrm{Hal}$ ini dapat diperlihatkan pada bervegetasi dengan lahan Tabel 4.

Tabel 4. Peningkatan Suhu Permukaan untuk Kawasan bervegetasi dan Lahan Terbangun Di Kota Pekanbaru Periode Tahun 1989 dan 2012

\begin{tabular}{llcc}
\hline \multirow{2}{*}{ No. } & \multicolumn{1}{c}{ Penutupan Lahan } & \multicolumn{2}{c}{ Suhu Permukaan $\left({ }^{\circ} \mathbf{C}\right)$} \\
\cline { 3 - 4 } & \multicolumn{1}{c}{$\begin{array}{c}\text { Tahun } \\
\mathbf{1 9 8 9}\end{array}$} & $\begin{array}{c}\text { Tahun } \\
\mathbf{2 0 1 2}\end{array}$ \\
\hline 1. & $\begin{array}{l}\text { Bervegetasi (Hutan, semak } \\
\text { belukar, padang rumput) }\end{array}$ & $10,94-18,32$ & $16,96-26,63$ \\
\hline 2. & $\begin{array}{l}\text { Kawasan Terbangun } \\
\text { (gedung perkantoran, jalan } \\
\text { aspal, Pemukiman, bangunan } \\
\text { ruko) }\end{array}$ & 13,95- 19,74 & $22,37-27,00$ \\
\hline & Sumber : Hasil Peneltian (Ikhwan, 2013)
\end{tabular}


Tabel 4 memperlihatkan bahwa suhu permukaan pada kawasan yang bervegetasi (seperti : hutan, semak belukar, padang rumput) memiliki suhu yang lebih rendah dibandingkan kawasan yang terbangun yang dibuat dari beton dan jalan aspal. Hasil penelitian Hidayati (2013) di Kota Yogyakarta juga menunjukkan

bahwa penggunaan lahan berupa lahan terbangun memiliki suhu yang lebih tinggi bila dibandingkan dengan penggunaan lahan yang lainnya, baik di tahun 1992 maupun di tahun 2009. Perbandingan diantara suhu lahan terbangun dengan penggunaan lahan lainnya juga menunjukan selisih yang relatif besar. Hal ini dapat disebabkan karena energi yang dipancarkan oleh lahan terbangun cenderung lebih besar untuk kemudian terekam oleh sensor satelit. Perbedaan penggunaan atap bangunan pada lahan terbangun akan mempengaruhi besarnya pancaran energi yang dipantulkan dari sumber energi yang didapat. Adanya perubahan penggunaan lahan di daerah perkotaan menjadi lahan terbangun dapat

meningkatkan suhu sekitar dan berdampak pada terjadinya fenomena Pulau Bahang atau Urban Heat Island.

\section{KESIMPULAN DAN SARAN}

\section{Kesimpulan}

1. Sebaran suhu permukaan di Kota Pekanbaru dan sekitarnya adalah antara $12,94^{\circ} \mathrm{C}$ (suhu permukaan terendah) sampai $30,38^{\circ} \mathrm{C}$ (suhu permukaan tertinggi). Suhu permukaan berkisar antara $24,73^{\circ} \mathrm{C}-30,38^{\circ} \mathrm{C}$ tersebar di pusat kota pemerintahan

dan pemukiman padat penduduk di Kecamatan Tampan, Kecamatan Bukit Raya dan Kecamatan Marpoyan 
Damai. Sementara itu, di luar kawasan Kota Pekanbaru, yaitu sebagian wilayah Kabupaten Kampar, suhu berkisar antara $12,94^{\circ} \mathrm{C}$ sampai $22,8^{\circ} \mathrm{C}$.

2. Fenomen Heat Island (pulau panas) di Kota Pekanbaru sudah mulai ada.

\section{Saran}

Adapun saran yang dapat dituliskan dari hasil penelitian ini, bahwa ntuk dapat mewujudkan Kota Pekanbaru yang memiliki iklim mikro yang ideal, mencegah dan mengurangi fenomena Heat Islands serta meningkatkan rasa nyaman, maka perlu dilakukan pengembangan ruang terbuka hijau khususnya di kawasankawasan terbangun seperti pemukiman, sepanjang jalan aspal, bangunan perkantoran dan ruko. Oleh karena itu perlu ada penelitian lebih lanjut tentang kombinasi antara tutupan lahan bervegetasi dengan lahan tidak bervegetasi, sehingga dapat diperoleh suhu permukaan tutupan lahan yang nyaman bagi masyarakat Kota Pekanbaru untuk beraktifitas.

\section{DAFTAR PUSTAKA}

Handayani. 2007. Identifikasi perubahan kapasitas panas kawasan perkotaan dengan menggunakan citra Landsat TM/ETM (studi kasus : kodya Bogor). Skripsi. Jurusan Geofisika dan Meteorologi. FMIPA IPB. Bogor.

Lillesand TM.. dan Kiefer RW. 1997. Penginderaan Jauh dan Interpretasi Citra. Cetakan Ketiga. Gadjah Mada University Press. Yogyakarta.

Lo. C.P. 1995. Penginderaan Jauh

Terapan

(Diterjemahkan oleh B. Purbowaseso). Universitas Indonesia. Jakarta

Ikhwan, Muhammad. 2013. Aplikasi Penginderaan Jauh untuk Mengidentifikasi Distribusi Suhu Pemukaan di Kota Pekanbaru. Tesis. Program Pascasarjana. Universitas Riau.

Tursilowati, Laras. (2002). Urban Heat Island

Dan 
Kontribusinya

Perubahan

Pada

Hubungannya

Iklim

Dan dengan

Perubahan Lahan. dalam

Prosiding Seminar Nasional

Pemanasan Global dan

Perubahan Global. Fakta. Mitigasi. Dan Adaptasi. Pusat Pemanfaatan Sains Atmosfer dan Iklim LAPAN. ISBN :978-979-17490-0-8 : 89-96

Tursilowati, Laras. 2007. Use Of Remote Sensing And Gis To Compute Temperature Humidity Index As Human Comfort Indicator Relate With Land Use-Land Cover Change (LULC) In Surabaya. The $73^{\text {th }}$ International Symposium on Sustainable
Humanosphere. Jurnal IImiah Esai 160:166

Sutanto. 1998. Penginderaan Jauh Jilid I. Gadjah Mada University Press. Yogyakarta.

Whardani. Diah Eka. 2006. Pengkajian Suhu Udara Dan Indeks Kenyamanan Dalam Hubungannya Dengan Ruang Terbuka Hijau (Studi Kasus Kota Semarang). Skripsi. Departemen Geofisika Dan Meteorologi. Fakultas Matematika Dan IImu Pengetahuan Alam. Institut Pertanian Bogor. Bogor 